\title{
ASSESSING GASTRIC ULCERATION IN FATTENING PIGS HOUSED WITHOUT OR WITH STRAW AND ADDITIONAL SPACE - A MACROSCOPIC AND MICROSCOPIC STUDY ON A CONVENTIONAL AUSTRIAN FARM
}

\begin{abstract}
Ines Krauss ${ }^{1}$, Lukas Schwarz ${ }^{1}$, Katharina Schodl ${ }^{4,5}$, Christian Knecht ${ }^{1}$, René Brunthaler ${ }^{3}$, Barbara Metzler-Zebeli², Christine Leeb ${ }^{5}$, Isabel Hennig-Pauka ${ }^{1,6 *}$

1University Clinic for Swine, ${ }^{2}$ Institute of Animal Nutrition and Functional Plant Compounds, Department for Farm Animals and Veterinary Public Health, ${ }^{3}$ Institute of Pathology and Forensic Veterinary Medicine, Department of Pathobiology, University of Veterinary Medicine, Veterinärplatz 1, 1210 Vienna, ${ }^{4}$ Division of Livestock Sciences, Department of Sustainable Agricultural Systems, ${ }^{5}$ Doctoral School of Sustainable Development, University of Natural Resources and Life Sciences, Gregor-Mendel-Straße 33, 1180 Vienna, ${ }^{6}$ Field station for Epidemiology, University of Veterinary Medicine Hannover, Büscheler Str. 9, 49456 Bakum, Germany
\end{abstract}

${ }^{*}$ Corresponding author, E-mail: isabel.hennig-pauka@vetmeduni.ac.at

\begin{abstract}
Gastric ulcerations in finishing pigs can cause growth restriction, sudden death and contamination of the carcass by invading microorganisms. The aim of the study was to compare macroscopic and histological findings of the stomach mucosa in fattening pigs kept at $1 \mathrm{~m}^{2} /$ pig and provided with long straw (10 groups, 113 pigs) with a control group kept at $0.7 \mathrm{~m}^{2} /$ pig without straw (11 groups, 120 pigs). At slaughter, the gastric health of pigs was assessed by macroscopic and histological scoring of 233 stomachs ranging from 0 (no alteration of mucosa) to 3 (ulceration). Gastric scores were correlated with organ alterations, carcass lesions and blood parameters. Based onto histological findings after gold standard sensitivity and specificity of macroscopic findings for ulceration (score 3 ) were $53 \%$ and $98 \%$, respectively. While the extent of mucosal alterations can be assessed by macroscopic scoring easily at slaughter, histological examination reveals the depth of alterations. Median group prevalences of gastric ulcerations diagnosed by macroscopic examination were $5 \%$ in the control group (range 0-40\%) and $18 \%$ in the straw group (range 0-50\%), with no significant difference between both groups. Macroscopic scores were significantly higher in the straw group. Prevalence of ear-tip lesions was positively correlated with gastric health $(p<0.05)$.

Analysis of particle size distribution in feed revealed, that more than $50 \%$ of the feed consist of particles with less than $0.5 \mathrm{~mm}$ in diameter. The fine-ground diet in this herd was therefore identified as an important risk factor for the development of gastric ulceration on this farm. As a conclusion, the known risk factor of a high proportion of small particles in diet was not compensated by possible positive effects of straw and more space, and should be eliminated with high priority.
\end{abstract}

Key words: eartip lesions; histology; mucosa alterations; stomach; straw; swine

\section{Introduction}

Ulcerations of the pars oesophagea (PO) in the stomach of pigs are considered to be a serious health and welfare problem in pig production with varying prevalences on different farms $(1,2)$.

Received:5July 2017

Accepted for publication: 25 September 2017
Although gastric ulceration (GU) is a severe disease that can even cause sudden death of the affected animal, precursors of GU such as different stages of hyperkeratosis or superficial epithelial damages do not necessarily cause clinical signs (3). Epithelial damage of the PO can occur rapidly but can also heal quickly $(4,5)$. After an initial proliferation of the affected mucosa, hyperkeratotic layers become fissured, resulting 
in small erosions as precursors of ulceration (6). Damage of blood vessels can cause chronic bleeding and mucosal leakage with the consequence of ingesta contamination of inner body surfaces. The entire process of ulcer development can take place within less than 24 hours $(5,7)$.

While the extent of mucosal damage can be quantified using a scoring scheme during macroscopic examination $(4,7,8)$, the depth of the erosions in a particular small area and early pathological alterations can be assessed by histological examination (6). The two techniques provide complementary information on gastric health.

Several predisposing factors for GU have been identified so far, but the pathogenesis has not yet been completely elucidated. Diet structure and composition, as pelleted or finely ground feed, have a major impact on the development of gastric lesions and are considered to be the most important risk factors (9-13). Overcrowding, grouping, transportation, environmental changes and feed withdrawal are assessed as stressful situations predisposing for GU development (1417). The provision of higher space per animal is expected to prevent GU development, because social stress is reduced $(18,19)$. It was shown that enrichment of a barren environment with straw enabling foraging and rooting behaviour of pigs reduced the development of gastric lesions (1820). The beneficial effect of straw was related to an increased structure and lower fluidity of the stomach contents, a higher concentration of short chain fatty acids and more saliva production due to increased chewing activity $(21,22)$.

The effect of straw and a higher space allowance on the gastric health of fattening pigs was evaluated in this fattening farm. Blood parameters and clinical data were analyzed for any correlation to gastric scores. The provision of straw in racks and more space per pig was expected to result in fewer stomach alterations. In addition, sensitivity and specificity of macroscopic examination of gastric mucosa were determined in comparison to histological findings.

\section{Materials and methods}

\section{Animals, groups and handling}

All animals were raised and handled on a commercial farm adhering to Austrian Animal
Welfare Legislation and feeding was in compliance with producer standards with respect to origin of protein feed (regional and GMO-free). Approval from the institutional Animal Care and Use Committee was not required as the work involved no special treatment outside of normal commercial practice.

In total, 590 Large White/German Landrace $\mathrm{x}$ Pietrain F2-cross-bred pigs, raised on a commercial pig fattening farm in Lower Austria, were included in the analysis of feed consumption and daily gain with feeding valve as the statistical unit. All pigs were randomly assigned to either straw group (SG, 248 pigs, 10 feeding valves) or control group (CG, 342 pigs, 11 feeding valves). Pigs were housed on fully slatted floor in groups of 16 pigs per pen $\left(0.7 \mathrm{~m}^{2}\right.$ space per pig) in the CG and in groups of 13 pigs per pen $\left(1 \mathrm{~m}^{2}\right.$ space per pig) in the SG. On arrival on the farm and immediately before slaughter the total weight of the pigs belonging to one feeding valve was recorded. Prior to slaughter, pigs were individually tattooed to allocate them to group and feeding valve at the abattoir. Pigs were slaughtered at the end of fattening within 3 weeks. At slaughter in total 233 pigs (114 female and 119 castrated males) were selected randomly from all feeding valve groups for evaluation of gastric health, inspection of skin, joint, lung and liver alterations and for blood sampling (CG: 120 pigs; SG: 113 pigs). The difference in gender distribution in both groups was not significant ( $p=0.64$, chi-square test).

In blood samples the number of leucocytes as a marker for inflammation, as well as haematocrit and haemoglobin for anaemia diagnostic were determined. The mean corpuscular haemoglobin concentration (MCHC) was calculated by dividing haemoglobin by haematocrit. Blood samples were analysed with an automatic cell counter following the manufacturer's instructions (IDEXX ProCyte $\mathrm{Dx}^{\mathrm{TM}}$, Idexx Laboratories, Ludwigsburg, Germany). To confirm results of differential cell counts, blood smears from all pigs were stained using HAEMA-LT-SYS ${ }^{\circledR}$ Quick-Stain (Diff-Quick) (Henry Schein, Germany) and 200 cells were differentiated at 1000 -fold magnification by eye using immersion oil according to routine methods.

\section{Feeding}

Feeding technique and diet composition was the same for all pigs. Liquid feeding with 4:1 water to feed ratio (approximately $25 \%$ dry matter 
content) was provided automatically by a sensor-controlled liquid feeding system three times a day, with multiple intervals of approximately two minutes at every feeding until satiation was achieved. The pig-to-feeding-place ratio was $1: 1$. In the SG individual pigs had more feeding space at the trough. The composition and chemical analysis of the conventional diet for finishing pigs with 14.7 $\mathrm{MJ} \mathrm{ME} / \mathrm{kg}$ dry matter is shown in table 1 . Fresh water was provided by one drinker per pen. Pigs in the SG had ad libitum access to long wheat straw, which was offered in racks above their feeding troughs. Fresh straw was provided by the farmer on a daily basis. Pigs consumed 110-150 g straw/day/pig.

\section{Macroscopic examination}

At the abattoir, stomachs were labelled individually and examined approximately 4 hours after exsanguination by opening the gastric wall at the large curvature. The stomach was emptied and the mucosal surface was cleaned with tap water. Mucosal alterations around the stomach's PO were quantified by the same person without knowledge of the group using the slightly modified macroscopic score (Table 2) of Straw et al. (4) and Große Liesner et al. (8). A macroscopic score of 3 corresponds to the clinical signs of
GU and was assessed as relevant disease with a probable impact on production parameters. Figures 1a-f illustrate findings corresponding to the macroscopic and histological scores.

During slaughter also carcass inspections were made and ear and tail lesions were recorded (no lesion=0; missing tissue $=1$ ). These lesions were diagnosed to be caused by biting, but any previous primary skin alterations, e.g. necroses or scarifications, could not be excluded. Joints, skin, liver and lungs of pigs were inspected macroscopically at the abattoir for alterations to assess the overall herd health status of the pigs.

\section{Histological examination of gastric mucosa}

Immediately after macroscopic scoring of the gastric mucosa, tissue pieces containing parts of the PO were sampled and fixed in $4 \%$ buffered formaldehyde solution. Samples were stored at room temperature for $48 \mathrm{~h}$, alcohol dehydrated and embedded in paraffin wax. Paraffin sections $(5 \mu \mathrm{m})$ were cut, stained with haematoxylin-eosin (HE) and inspected by light microscopy (Olympus CX21, Olympus Corporation, Japan) according to routine methods. Histological tissue alterations were quantified using a modified histological score (Table 2) according to Embaye et al. (6) and Eisemann and Argenzio (16).

Table 1: Composition and analysis of the extruded formulated diet

\begin{tabular}{|l|c|}
\hline Ingredients & \% of diet formulation \\
\hline barley & 13,5 \\
\hline corn silage & 50,8 \\
\hline rapseed meal & 12,7 \\
\hline Mineral and vitamin mix & 6,2 \\
\hline $\mathrm{H}_{2} \mathrm{O}$ & 16,8 \\
\hline Chemical analysis & (g/kg dry matter content) \\
\hline dry matter & 1000 \\
\hline crude protein & 145 \\
\hline crude fat & 38 \\
\hline crude fibre & 51 \\
\hline nitrogen-free extract & 717 \\
\hline ash & 48 \\
\hline starch & 565 \\
\hline
\end{tabular}


Table 2: Results of modified macroscopic $(4,8)$ and histological $(6,16)$ scores of the pars oesophagea (PO) of gastric mucosa in all examined pigs. Macroscopic and histological scores of 0 and 3 are corresponding, while the other identical macroscopic and histological scores did not refer to the same pathological alterations

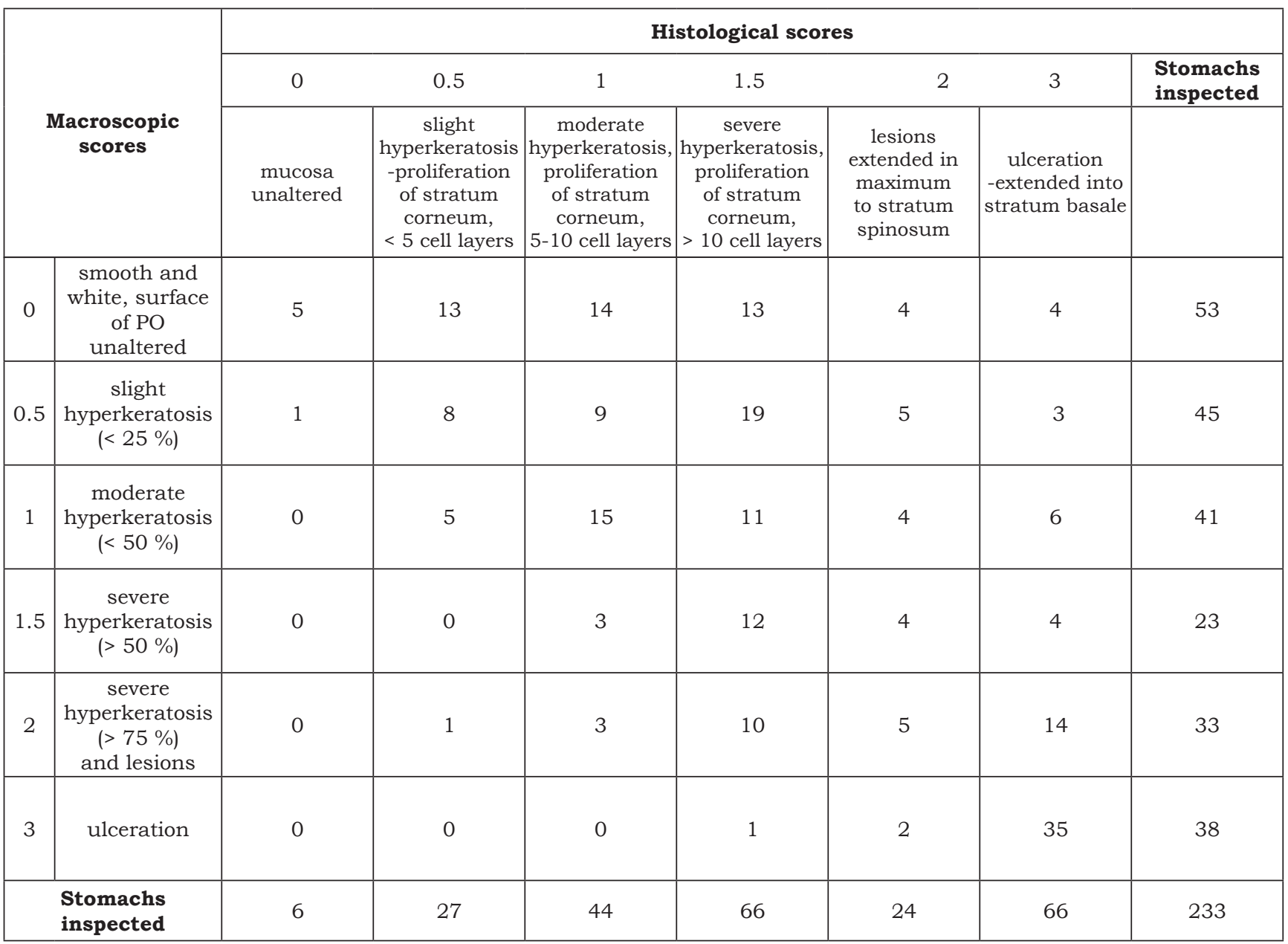

Table 3: Comparison of mean health and blood parameters. Reference ranges for blood parameters in fattening pigs were shown in brackets (23)

\begin{tabular}{|c|c|c|c|}
\hline & Straw group $(n=113)$ & Control group $(n=120)$ & \\
\hline & $\begin{array}{l}\text { Mean+standard deviation } \\
\text { (range) }\end{array}$ & $\begin{array}{c}\text { Mean+standard deviation } \\
\text { (range) }\end{array}$ & $\mathrm{p}$ \\
\hline $\begin{array}{l}\text { Macroscopic gastric health score } \\
\text { (score } 0-3)\end{array}$ & $\begin{array}{c}1.4+1.1 \\
(0-3)\end{array}$ & $\begin{array}{c}1.0+0.9 \\
(0-3)\end{array}$ & 0.02 \\
\hline $\begin{array}{l}\text { Histological gastric health score } \\
(\text { score } 0-3)\end{array}$ & $\begin{array}{l}1.9 \pm 1.0 \\
(0-3)\end{array}$ & $\begin{array}{c}1.6+0.8 \\
(0-3)\end{array}$ & 0.23 \\
\hline $\begin{array}{l}\text { Leukocytes }(\mathrm{G} / 1) \\
\text { (reference range: } 12.0-24.6 \mathrm{G} / 1 \text { ) }\end{array}$ & $\begin{array}{l}19.51 \pm 4.37 \\
(8.75-35.84)\end{array}$ & $\begin{array}{c}19.83 \pm 3.85 \\
(11.84-32.09)\end{array}$ & 0.86 \\
\hline $\begin{array}{l}\text { Haematocrit }(1 / 1) \\
\text { (reference range: } 0.3-0.41 / 1)\end{array}$ & $\begin{array}{l}0.49 \pm 0.03 \\
(0.41-0.59)\end{array}$ & $\begin{array}{l}0.49 \pm 0.04 \\
(0.32-0.59)\end{array}$ & 0.69 \\
\hline $\begin{array}{l}\text { Haemoglobin }(\mathrm{g} / 1) \\
\text { (reference range: } 100-147 \mathrm{~g} / 1)\end{array}$ & $\begin{array}{c}150 \pm 82 \\
(115-179)\end{array}$ & $\begin{array}{l}148+11 \\
(97-168)\end{array}$ & 0.69 \\
\hline $\begin{array}{l}\text { Mean corpuscular haemoglobin } \\
\text { concentration }(\mathrm{MCHC}),(\mathrm{g} / 1) \\
\text { (reference range } 317-370 \mathrm{~g} / 1 \text { ) }\end{array}$ & $\begin{array}{c}302+93 \\
(278-321)\end{array}$ & $\begin{array}{c}299+8 \\
(275-318)\end{array}$ & $<0.01$ \\
\hline
\end{tabular}


Blinded histological scoring was performed separately by a professional pathologist and by a clinician and findings were reassessed in the case of diverging scores. Histological scores 0 and 3 correspond to the macroscopic scores. Other identical macroscopic and histological scores did not refer to the same pathological alterations and could therefore not be compared.

\section{Statistical analysis}

Statistical analysis was performed using the statistical software package SPSS $^{\circledR}$ version 20 (IBM Corp., Armonk, New York) as well as SAS (Version 9.4, SAS Inst. Inc., Cary, NC, USA).

Parameters were first analyzed for normality using Shapiro-Wilk test with the PROC UNIVARIATE method in SAS (Version 9.4, SAS Inst. Inc., Cary, NC, USA). Proportion of pigs with respective scores belonging to one feeding valve were used for statistical comparison of $\mathrm{CG}$ and SG, with $n=11$ for control pigs (CG) and $n=10$ for pigs provided with straw and more space (SG). Spearman's rank correlation coefficients calculated between different quantitative parameters (macroscopic and histological gastric scores, leucocytes, haemoglobin, haematocrit, mean corpuscular haemoglobin concentration (MCHC), proportions of pigs with tail and ear-tip alterations) were tested for significance $(p<0.05)$.

The Cook's distance (Cook's D) test was used to determine any influential observation on the model. Data were analyzed by ANOVA using the MIXED procedure in SAS. The final model included the fixed effects group, sex and their twoway interaction and the random effect 'feeder'. The experimental unit was pig nested within number per pigs per feeder. As the pig's body weight at the start of the experiment was different in the two pig groups, pig's starting body weight was used as covariate in the model for the weight at slaughter. As the growing days differed among pigs, they were significant for most parameters and were included as co-variate in the final model. Degrees of freedom were approximated by the method of Kenward-Roger. The Tukey-Kramer test was used for pairwise comparisons between least squares means.

\section{Results}

At the age of 12 weeks the pigs weighed 31.4 $\pm 1,5 \mathrm{~kg}$ and were slaughtered with $127 \pm 7,9$ $\mathrm{kg}$ body weight. The mean daily weight gain in feeding valve groups was $850 \mathrm{~g} \pm 140 \mathrm{~g}$ and did not differ between pigs provided with straw and more space and control pigs. No acute gastric ulcerations were observed and all mucosal alterations were assessed as chronic as ulcers were surrounded by hyperkeratotic regions. Long unchewed straw stems were a frequent finding in the stomach content of the SG pigs. Macroscopic and microscopic scores are summarized in table 2 . The sensitivity of macroscopic detection of GU (score 3) was $53 \%$ allocated to histological findings, while the specificity was $98 \%$.

The median prevalence of pigs in one feeding valve group with score 3 was $18 \%$ (range 0-50 \%) in the SG compared to $5 \%(0-40 \%)$ in the CG $(p=0.61)$. The median prevalence of pigs with histological score 3 was $34 \%$ (range 0-64\%) in the SG, compared to $11 \%$ (range 0-62\%) in the CG $(p=0.25)$. Statistical mixed model calculations resulted in higher macroscopic scores in pigs provided with straw compared to control pigs $(p=0.02)$, whereby male pigs had a higher macroscopic score than female pigs $(p=0.02)$. Histological scores did not differ between the two groups, but were generally greater in males compared to female pigs ( $p=0.01)$. Haematocrit and haemoglobin were similar between pig groups and sexes. Pigs provided with straw had an increased MCHC (standard calculation: Haemoglobin/ Haematocrit), compared to control pigs. The MCHC was similar between both sexes. Ranges of red blood parameters measured within the groups were beyond the published reference ranges (Table 3). There were no correlations between haematocrit, haemoglobin concentration or MCHC with the gastric health scores. The statistical comparison of pigs with macroscopically or histologically defined GU (score 3) with pigs with lower gastric scores resulted in no differences in the red blood parameters. The mean carcass weight after the slaughtering process was slightly higher $(p=0.03)$ in the straw group $(105.3 \mathrm{~kg})$ compared to the control group $(101.6 \mathrm{~kg})$. Pigs provided with straw and more space had a higher mean total feed consumption $(268 \mathrm{~kg})$ compared to control pigs during the fattening period $(259 \mathrm{~kg}, \mathrm{p}<0.01)$. 

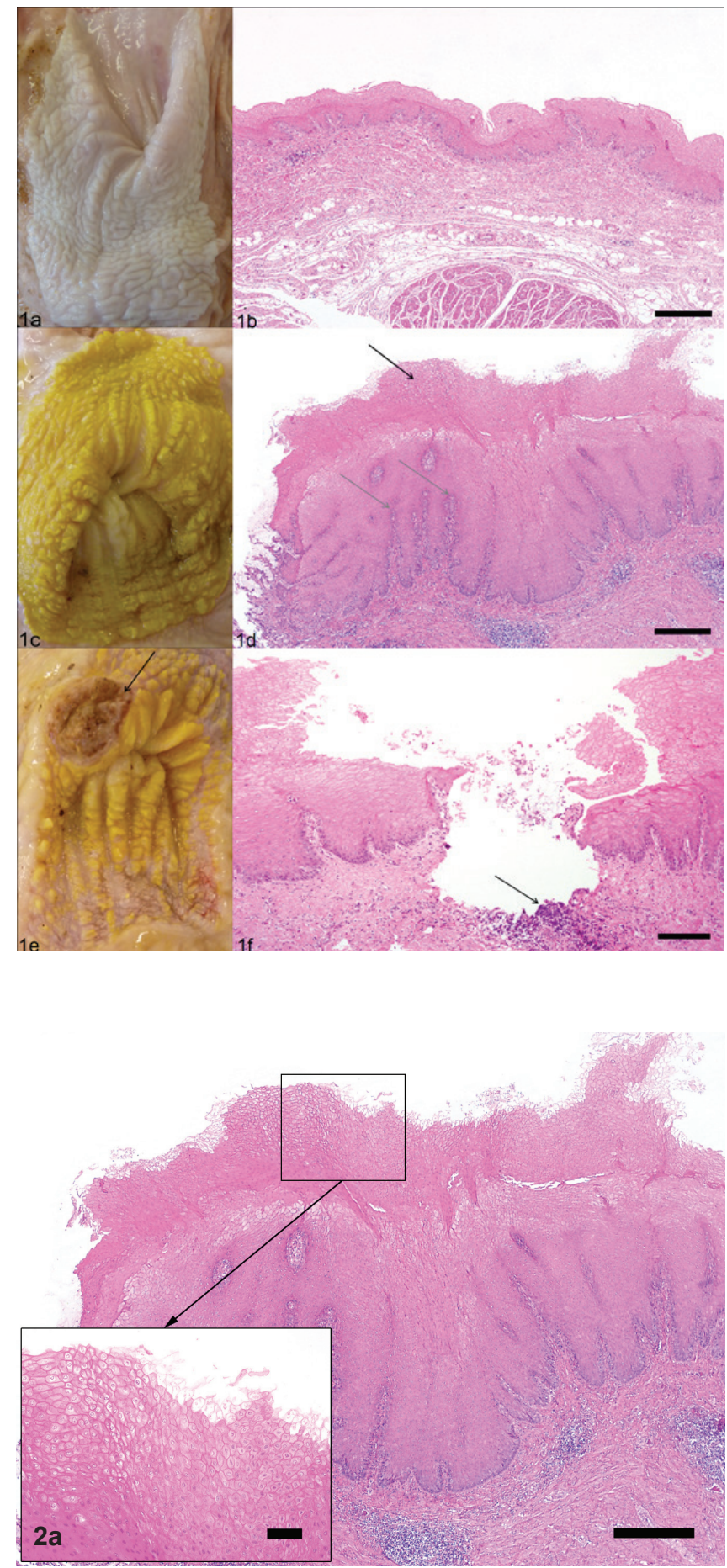

Figure 1a-f: Pictures of stomachs pars oesophagea (PO) scored using the modified macroscopic score (MS 0-3) according to Straw et al. (4) and Grosse Liesner et al. (8) and corresponding histological slides scored using the modified histological score (HS 0-3) according to Embaye et al. (6) and Eisemann and Argenzio (16)

Fig. 1a. Unaltered PO with smooth and white surface, MS 0. Fig. 1b. Unaltered PO, HS 0. Haematoxylin and eosin (HE), scale bar length $400 \mu \mathrm{m}$. Fig. 1c. Severe Hyperkeratosis $>50 \%$ of PO, MS 1.5. Fig. 1d. Severe Hyperkeratosis $>50 \%$, cells with pallor cytoplasma (black arrow) and extended papillae of lamina propria (grey

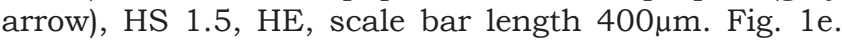
Hyperkeratosis of PO, ulcer (black arrow), MS 3. Fig. 1 . Hyperkeratosis of $\mathrm{PO}$, ulceration extending throughout the basal membrane (black arrow), HS 3, HE, scale bar length $150 \mu \mathrm{m}$.

Figure 2a-b: Higher magnification of Fig. 1d to illustrate cells with pallor cytoplasma (Fig. 2a.) and enlarged papillae (Fig. 2b.), scale bar length $400 \mu \mathrm{m}$ and for higher magnification $80 \mu \mathrm{m}$

The overall average prevalence of ear-tip lesions was $10 \pm 14 \%$ and was positively correlated with the prevalence of GUs (macroscopic GU: $r_{\mathrm{sp}}=0.55$, $\mathrm{p}=0.016$, histological GU: $\left.\mathrm{r}_{\mathrm{sp}}=0.67, \mathrm{p}=0.002\right)$ and with the gastric health scores (macroscopic score: $r_{\mathrm{sp}}=0.51, \mathrm{p}=0.02$, histological score: $\mathrm{r}_{\mathrm{sp}}=0.58$,

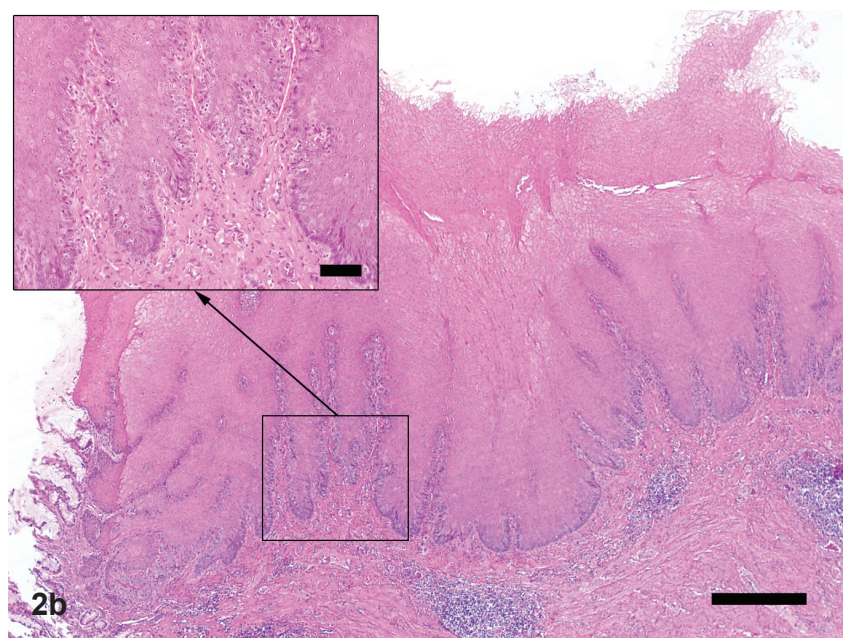

$\mathrm{p}=0.009$ ). No additional correlations between gastric health scores and other parameters were found. Lung health status in the herd was assessed to be acceptable, because no clinical signs of disease were observed during the study period and only slight lung alterations were found 
at slaughter in $22 \%$ of the pigs. In $5 \%$ of the animals few milk spots were detected in the liver.

\section{Discussion}

The prevalence of GU on this farm is comparable to those reported in other European countries $(1,21)$. Compared to histological findings, macroscopic examination at the abattoir resulted in a high specificity of $98 \%$ but a low sensitivity for the detection of GU (score 3). This is in accordance with the study of Embaye et al. (6), who reported a moderate to poor correlation between gross pathology and histological findings. A comparison between gastric lesion scores determined by gastroscopy using a flexible videoscope, by necropsy and by histopathology resulted in a poor (gastroscopy versus necropsy) or moderate (necropsy versus histopathology) agreement between the methods (24). Both scoring methods provide different information on the mucosal alterations: while the macroscopic score allows the assessment of the spatial extension of lesions, the histological score reveals the depth of tissue layers affected. Pigs with deep but small ulcerations can appear to be healthy if the blood loss is minimal (25), but negative effects on growth performance can be expected (7). While GU is of high clinical relevance, slight histological alterations characterized by a proliferation of the Stratum corneum are often found in healthy pigs (4).

In either groups mucosal alterations of varying severity were found and prevalence varied between feeding valve groups. Inflammatory or anaemic conditions were assessed to be of minor impact in this herd for the overall health status. This was deduced from the mainly physiological findings for white and red blood cells in majority of the pigs in both groups. In addition, examination of carcasses at the slaughterhouse revealed slight pneumonic lesions in $22 \%$ of slaughter pigs, which is in accordance with other reports of organ findings at slaughter in Austria (26). From the slightly higher MCHC in SG pigs, which is a calculated parameter useful to diagnose anaemia due to iron deficiency in pigs, no conclusion can be drawn, because haemoglobin and haematocrit did not differ between groups.

Although all groups were fed the same diet and all pens were equal, other unknown predisposing factors within groups, e.g. social stress, cannot be excluded (22). Gender was included as a fixed effect in the statistical model and had a significant influence on the severity of gastric alterations, but not on weight or blood parameters. Pigs provided with straw and more space had slightly higher feed consumption during fattening and therefor also a higher uptake of fine-ground diet. This increased exposition to a major risk factor might have been decisive for the outcome of this study, because one of the most important predisposing factors for GU is feed with a high percentage of small particles $(9,12,13)$. A high proportion $(>36 \%)$ of very fine particles $(<0.4 \mathrm{~mm})$ was associated with a high risk of GU development (12) and therefore an appropriate parameter for risk assessment. Grosse Liesner et al. (8) described a higher risk for GU if feed contains more than $20 \%$ of particles smaller than $0.4 \mathrm{~mm}$. In this study the fraction of particles $<0.5 \mathrm{~mm}$ was higher than $50 \%$ in the fattening diet, which is comparable to ulcerogenic diets in other trials (13). Particle size distribution on this farm can be considered as an important predisposing factor for GU, so that even enhanced conditions such as the provision of straw and the allocation of increased space were not able not improve gastric health in this study. In the study of Eisemann and Argenzio (16) only a beneficial effect of adequate diet structure but not of space per pig was stated. In contrast, floor type and bedding material especially in the lying area were found to have high impact on gastric health (19). Nielsen and Ingvartsen (27) reported a preventive effect of straw when a finely ground diet was fed. In some stomach contents they also found long straw stems, suggesting that pigs had swallowed straw without chewing it. In the study of Herskin et al. (28) only higher amounts of straw $(500 \mathrm{~g} / \mathrm{pig} /$ day) were able to reduce GU prevalences, while gastric scores did not differ between pigs provided with different amounts of straw (10-1000g/pig/ day). Although feasable, the amount of up to 150 $\mathrm{g}$ straw per pig and day provided in racks and not on the floor as described in this study, might not be adequate to reduce GU prevalence. In a recent study of Jensen et al. (22) up to 300 g straw per pig and day provided on the floor decreased the risk of GU development. Also in that study GU development was not eliminated completely by straw provision, which was supposed to be due to a high proportion of pelleted and finely-ground diet as a pre-disposing risk factor.

There are some reports from other species, that unchewed straw stems mechanically irritate an 
already pre-damaged mucosa of the PO. In horses, Luthersson et al. (29) found significantly more GU when horses were fed with straw, which was deduced to the fact, that the straw was had not been chewed thoroughly and led to mechanical irritation of the gastric mucosa (29). In veal calves fed with wheat straw more erosions and ulcers in the abomasum were found (30). The authors hypothesized a partial blockage of the pyloric exit by straw and a mucosal damage by a mechanical abrasive effect of straw.

The correlation between the prevalence of ear-tip lesions, which were diagnosed to be the consequence of ear biting, and GU on this farm revealed that gastric health and other health parameters might influence one another. Whether pigs with GU had previously suffered from stress (e.g. social stress) or whether primary skin lesions at the ears as necroses or scarifications had been the original trigger factors for ear-biting, could not be assessed. Ear lesions with their relatively low prevalence and mild form on this farm had not been realized as a herd health problem by the farmer at the time of the study or in the past. However, stress could be one of the reasons for the development of GUs and vice versa (31). It is hypothetical, if GUs can increase the risk of ear biting. According to empirical reports, it is assumed that increased chewing leads to more production of saliva with its buffering components and can be triggered by gastrointestinal disorders $(32,33)$. In a previous study a relation between abnormal oral behavior, as increased chewing, and gastric ulceration was found (34).

For pigs, various dietary fibre sources such as straw, hay or sunflower hulls are used as feed and as suitable manipulable material for rooting and chewing. Dietary fibres contain NSP (nonstarch polysaccharides) as pectins, cellulose, hemicelluloses, ß-glucans and fructans (35). Dietary fibres have generally low energetic value, could stimulate satiation and reduce feed intake (36). Different fibre sources vary in their waterholding capacity, which is generally high. In the case of stem-rich material, as hay or straw, the material can be bulky due to their coarse structure (37). All fibre sources differ in their digestibility and fermentability based on content of NDF (neutral detergent fibre) and ADF (acid detergent fibre). The digestibility of dietary fibre increases with age of swine. Hay is more digestible than straw because of its less NDF content (38) and may lead to a better feeling of satiety. For the case reported here, other options for provision of manipulable material as well as alternative sources can be taken into account as a supplementation to diet.

\section{Conclusion}

Gastric health examination during routine carcass monitoring at the abattoir can support decision-making for analysis of GU predisposing factors on farm and for rapid preventive interventions. In this study no difference in the GU prevalence was found between pigs provided with straw and more space and those kept under conventional conditions. As a main predisposing factor, a high fraction of small feed particles in diet was identified. Gastric scores were higher in pigs provided with straw and more space. A positive correlation between ear tip lesions and gastric scores indicate that either both diseases influence each other or were triggered by the same factors on this farm.

\section{Acknowledgments}

This project received financial support from Austrian Billa AG. We thank for the support of farmers and abattoirs, Pamela Lakits and Michaela Koch and the entire team of the University Clinic for Swine of the University of Veterinary Medicine, Vienna.

\section{References}

1. Guise HJ, Carlyle WWH, Penny RHC, et al. Gastric ulcers in finishing pigs: their prevalence and failure to influence growth rate. Vet Rec 1997; 141: 563-6.

2. Swaby H, Gregory NG. A note on the frequency of gastric ulcers detected during post-mortem examination at a pig abattoir. Meat Sci 2012; 90: 269-71.

3. Elbers ARW, Hessing MJC, Tielen MJM, et al. Effect of oesophagogastric lesions on growth performance of finishing pigs. Kenya Vet 1984; 18: 87-9.

4. Straw B, Henry S, Nelssen J, et al. Prevalence of lesions in the pars esophagea of normal and sick pigs. In: Proceedings of the $12^{\text {th }}$ IPVS Congress. The Hague, Netherlands, 1995: 386. 
5. Doster AR. Porcine gastric ulcer. Vet Clin North Am Food Anim Pract 2000; 16: 163-74.

6. Embaye H, Thomlinson JR, Lawrence TLJ. Histopathology of oesophagogastric lesions in pigs. J Comp Pathol 1990; 103: 253-64.

7. Ayles HL, Friendship RM, Ball RO. Effect of dietary particle size on gastric ulcers, assessed by endoscopic examination, and relationship between ulcer severity and growth performance of individually fed pigs. Swine Health Prod 1996; 4: 211-6.

8. Grosse Liesner V, Taube V, Leonhard-Marek $\mathrm{S}$, et al. Integrity of gastric mucosa in reared piglets: effects of physical form of diets (meal/pellets), pre-processing grinding (coarse/fine) and addition of lignocellulose (0/2.5\%). J Anim Physiol Anim Nutr 2009; 93: 373-80.

9. Maxwell CV, Reimann EM, Hoekstra WG, et al. Effect of dietary particle size on lesion development and on the contents of various regions of the swine stomach. J Anim Sci 1970; 30: 911-22.

10. Wondra KJ, Hancock JD, Behnke KC, et al. Effects of particle size and pelleting on growth performance, nutrient digestibility, and stomach morphology in finishing pigs. J Anim Sci 1995; 73: 757-63.

11. Cole JT, Gookin JL, Gayle JM, et al. Endoscopy via a gastric cannula to monitor the development of ulcers in the pars esophagea in pigs after consumption of a finely ground feed combined with a period of withholding of feed. Am J Vet Res 2002; 63: 1076-82.

12. Cappai MG, Picciau M, Pinna W. Ulcerogenic risk assessment of diets for pigs in relation to gastric lesion prevalence. BMC Vet Res 2013; 8: e36 (8 pp.). https://bmcvetres.biomedcentral. com/articles / 10.1186/1746-6148-9-36

13. Mößeler A, Wintermann MF, Beyerbach M, et al. Effects of grinding intensity and pelleting of the diet - fed either dry or liquid - on intragastric milieu, gastric lesions and performance of swine. Anim Feed Sci Technol 2014; 194: 113-20.

14. Hessing MJC, Geudeke MJ, Scheepens CJ, et al. Mucosal lesions in the pars esophagus in swine: prevalence and the effect of stress. Tijdschr Diergeneeskd 1992; 117: 445-50.

15. Lawrence BV, Anderson DB, Adeola O, et al. Changes in pars esophageal tissue appearance of the porcine stomach in response to transportation, feed deprivation, and diet composition. J Anim Sci 1998; 76: 788-95.

16. Eisemann JH, Argenzio RA. Effects of diet and housing density on growth and stomach mor- phology in pigs. J Anim Sci 1999; 77: 2709-14.

17. Eisemann JH, Morrow WEM, See MT, et al. Effect of feed withdrawal prior to slaughter on prevalence of gastric ulcers in pigs. J Am Vet Med Assoc 2002; 220: 503-506.

18. Guy JH, Rowlinson P, Chadwick JP, et al. Health conditions of two genotypes of growing-finishing pig in three different housing systems: implications for welfare. Livest Prod Sci 2002; 75: 233-43.

19. Amory JR, Mackenzie AM, Pearce GP. Factors in the housing environment of finisher pigs associated with the development of gastric ulcers. Vet Rec 2006; 158: 260-64.

20. Bolhuis JE, Van den Brand H, Staals S, et al. Effects of pregelatinized vs. native potato starch on intestinal weight and stomach lesions of pigs housed in barren pens or on straw bedding. Livest Sci 2007; 109: 108-10.

21. Di Martino G, Capello K, Scollo A, et al. Continuous straw provision reduces prevalence of oesophago-gastric ulcer in pigs slaughtered at $170 \mathrm{~kg}$ (heavy pigs). Res Vet Sci 2013; 95: 1271-3.

22. Jensen KH, Jørgsen L, Haugegaard S, et al. The dose-response relationship between the amount of straw provided on the floor and gastric ulceration of pars oesophagea in growing pigs. Res Vet Sci 2017; 112: 66-74.

23. Nerbas E. Aktualisierung von Blutparametern beim Schwein: Dissertation. Hannover: University of Veterinary Medicine, 2008.

24. Mackin AJ, Friendship RM, Wilcock BP, et al. Development and evaluation of an endoscopic technique permitting rapid visualization of the cardiac region of the porcine stomach. Can $\mathrm{J}$ Vet Res 1997; 61: 121-7.

25. Friendship RM. Gastric ulceration in swine. Swine Health Prod 2004; 12: 34-5.

26. Schleicher S, Scheriau I, Kopacka S, et al. Analysis of the variation in meat inspection of pigs using variance partitioning. Prev Vet Med 2013; 111: 278-85.

27. Nielsen EK, Ingvartsen KL. Effects of cereal disintegration method, feeding method and straw as bedding on stomach characteristics including ulcers and performance in growing pigs. Acta Agric Scand A Anim Sci 2000; 50: 30-8.

28. Herskin MS, Jensen HE, Jespersen A, et al. Impact of the amount of straw provided to pigs kept in intensive production conditions on the occurrence and severity of gastric ulceration at slaughter. Res Vet Sci 2016; 104: 200-6. 
29. Luthersson N, Nielsen K, Harris P, et al. Risk factors associated with equine gastric ulceration syndrome (EGUS) in 201 horses in Denmark. Equine Vet J 2009; 41: 625-30.

30. Mattiello S, Canali E, Ferrante V, et al. The provision of solid feeds to veal calves: II. Behavior, physiology, and abomasal damage. J Anim Sci 2002; 80: 367-75.

31. Ekkel ED, Savenije B, Schouten WGP, et al. Health, welfare, and productivity of pigs housed under specific-stress-free conditions in comparison with two-site systems. J Anim Sci 1996; 74: 2081-7.

32. Bergeron R, Badnell-Waters AJ, Lambton $\mathrm{S}$, et al. Stereotypic oral behaviour in captive ungulates: foraging, diet and gastrointestinal function. In: Mason G, Rushen J, eds. Stereotypic animal behaviour. Fundamentals and applications to welfare. $2^{\text {nd }}$ ed. Wallingford: CABI, 2006: 19-57.

33. Cheeke PR, Dierenfeld ES. Digestive physiology: autoenzymatic digesters. In: Cheeke PR, Dierenfeld ES, eds. Comparative animal nutrition and metabolism. Wallingford: CABI, 2010: 11-21.

34. Dybkjaer L, Vraa-Andersen L, Pailey LG, et al. Associations between behaviour and stomach lesions in slaughter pigs. Prev Vet Med 1994; 19: 101-12.

35. Bindelle J, Leterme P, Buldgen A. Nutritional and environmental consequences of dietary fibre in pig nutrition: a review. Biotechnol Agron Soc Environ 2008; 12: 69-80.

36. Kirchgessner M, Stangl GI, Schwarz FJ, et al. Schweinefütterung. In: Kirchgessner M, Hrsg. Tierernährung: Ein Leitfaden für Studium, Beratung und Praxis. 14. Aufl. Frankfurt am Main: DLG-Verlags, 2014: 243-354.

37. Noblet J, Le Goff G. Effect of dietary fibre on the energy value of feeds for pigs. Anim Feed Sci Technol, 2001; 90: 35-52.

38. Kamphues J, Coenen M, Wolf $\mathrm{P}$, et al. Ernährung verschiedener Spezies. In: Kamphues J, Hrsg. Supplemente zur Tierernährung für Studium und Praxis. 12. Aufl. Hannover: M. \& H. Schaper, 2014: 296.

\title{
OCENJEVANJE GASTRIČNIH ULKUSOV PRI PRAŠIČIH PITANCIH, NASTANJENIH Z NASTILJEM ALI BREZ NASTILJA IN DODATNEGA PROSTORA - MAKROSKOPSKA IN MIKROSKOPSKA ŠTUDIJA NA KONVENCIONALNIH AVSTRIJSKIH KMETIJAH
}

\author{
I. Krauss, L. Schwarz, K. Schodl, C. Knecht, R. Brunthaler, B. Metzler-Zebeli, C. Leeb, I. Hennig-Pauka
}

Povzetek: Gastrične ulceracije pri prašičih pitancih v zaključni fazi lahko povzročijo omejevanje rasti, nenadno smrt in kontami-
nacijo trupa z invazivnimi mikroorganizmi. Cilj raziskave je bil primerjava makroskopskih in histoloških ugotovitev v sluznici želod-
ca pri pitovnih prašičih, ki so nastanjeni na $1 \mathrm{~m}^{2} /$ prašiča in imajo nastilj sestavljen iz dolge slame (10 skupin, 113 prašičev) v prim-
erjavi s kontrolno skupino, ki je bila nastanjena na 0,7 m²/prašiča in z nastiljem brez slame (11 skupin, 120 prašičev). Pri zakolu je
bilo želodčno zdravje prašičev ocenjeno z makroskopskim in histološkim točkovanjem, opravljenem na 233 želodcih, z ocenami,
ki se gibljejo od 0 (brez spremembe sluznice) do 3 (ulceracija). Rezultate opazovanj sluznice želodcev smo nato povezali s spre-
membami organa, poškodbami trupa in krvnimi parametri.
Medtem ko se obseg sprememb sluznice lahko oceni z makroskopskim merjenjem pri zakolu, histološki pregled razkrije globino
sprememb. Mediana prevalencaželodčnih ulkusov, diagnosticiranih z makroskopskim pregledom, je bila $5 \%$ v kontrolni skupini
(razpon od 0 do 40 \%) in 18 \% v skupini z nastiljem iz slame (razpon od 0 do 50 \%), pri čemer ni bilo opaziti značilne razlike med
skupinama. Makroskopski rezultati so bili precej višji v skupini z nastiljem iz slame. Razširjenost poškodb ušes je bila pozitivno
povezana z zdravjem želodca ( $(p<0,05$ ). Analiza porazdelitve velikosti delcev v krmi je pokazala, da več kot 50 \% krme sestavljajo
delci s premerom manj kot $0,5 \mathrm{~mm}$. Prehrana z drobno zmleto krmo je bila v čredi opredeljena kot pomemben dejavnik tveganja
za razvoj razjed želodca. Znani faktor tveganja z velikim deležem majhnih delcev v prehrani ni bil kompenziran z morebitnimi pozitivnimi učinki slame in več prostora, zato ga je treba iz reje čim prej odpraviti.

Ključne besede: poškodbe navrhuušesa; histologija; spremembe želodčne sluznice; želodec; slama; prašiči 